\title{
DARI TRADISIONAL KE MODERN: K.H. HIDAYAT RUHIYAT SIRODJ DAN PESANTREN ALBIDAYAH TAHUN 1971-2011
}

\author{
Oleh: \\ Ratna Isnaeni Tesdy, Wawan Darmawan, Ayi Budi Santosa ${ }^{1}$
}

\begin{abstract}
This study aimed to elaborate on the influence of Kiai Haji Yayat Ruhiyat Sirodj leadership to boarding school's education development. Albidayah Boarding School is a modern boarding school which still maintain traditional elements. Albidayah Boarding School's development cannot be apart from one of the figures that once led, namely Kiai Haji Yayat Ruhiyat Sirodj. The main problem in this research is "how was the education system of Albidayah Boarding School under the leadership of Kiai Haji Yayat Ruhiyat Sirodj in 1971-2011?”. This problem was examined by using a historical method that includes heuristic, critics, interpretation, and historiography. For data collection and research sources, conducted with literature study and history's witness interviews. Results study showed that under the leadership of Kiai Haji Yayat Ruhiyat Sirodj, Albidayah Boarding School has a significant development in the education field. Began with the traditional Islamic boarding school education (salafi) and developed into a modern boarding school (khalafi) by combining religion and general knowledge. The changing in the education system in Kiai Haji Yayat Ruhiyat Sirodj leadership era was made Albidayah Boarding School as official education institution under the government to build SP-IAIN (Sekolah Persiapan-Institut Agama Islam Negeri/ School Preparation-the State of Islamic Institute) in 1971. Then in 1993, Madrasah Aliyah (MA) Albidayah was built and in 2006 an Integrated Madrasah Tsanawiyah (MTs) Albidayah was also built. The curriculum that used by Albidayah Boarding School is an integrated curriculum that covers Boarding School Curriculum, the Ministry of Education and Culture Curriculum, and the Ministry of Religion Curriculum.
\end{abstract}

Keywords: Albidayah Boarding School, Education of Pondok Pesantren, Modern Pesantren, Yayat Ruhiyat Sirodj

\section{PENDAHULUAN}

Pendidikan di Indonesia terus mengalami perubahan, termasuk pendidikan Islam. Seiring dengan perkembangan zaman tentunya banyak tantangan yang harus di hadapai. Mulai dari masalah etika, moralitas, hingga isu-isu nasional dan global. Pendidikan Islam juga harus mampu menghadapi tantangan perkembangan zaman tanpa harus meninggalkan ajaran-ajaran Islam. Tantangan tersebut juga harus dihadapi oleh pondok pesantren dalam memberikan pembelajaran pada santri-

\footnotetext{
${ }^{1}$ Ratna Isnaeni Tesdy adalah mahasiswa pada Departemen Pendidikan Sejarah FPIPS UPI, Ayi Budi Santosa dan Wawan Darmawan adalah dosen pembimbing. Penulis dapat dihubungi di alamat email : email ratnaisnaeni@gmail.com
} 
santrinya. Hal ini yang menjadi salah satu faktor pendorong pondok pesantren yang berkembang dari tipe salafi ke khalafi.

Pondok pesantren yang masih menunjukkan eksistensinya hingga saat ini yaitu Pesantren Albidayah yang terdapat di Desa Giriasih, Kecamatan Batujajar, Kabupaten Bandung Barat. Pondok Pesantren Albidayah merupakan salah satu pesantren yang mengalami perubahan seiring dengan perkembangan zaman. Perubahan pesantren dari salafi ke khalafi tentu tidak terlepas dari gaya kepemimpinan Kiai. Karena Kiai yang memimpin pondok pesantren akan menentukan perkembangan pendidikan pesantren itu sendiri. Kiai senantiasa melakukan pembaharuan-pembaharuan dalam berbagai bidang terutama dalam bidang pendidikan. Dalam perkembangannya Pesantren Albidayah sudah dipimpin oleh empat Kiai secara turun temurun. Dari keempat Kiai yang memimpin tersebut memiliki ciri khasnya masing-masing. Namun perubahan pondok Pesantren Albidayah yang sangat signifikan yaitu pada masa Kiai Haji Yayat Ruhiyat Sirodj. Pada masa kepemimpinan beliau, Albidayah mengalami perubahan yang besar yaitu menjadikan Pesantren Albidayah sebagai lembaga pendidikan di bawah pemerintah.

Pondok pesantren yang menjadi lembaga resmi di bawah pemerintah tentunya akan mengalami perubahan dalam berbagai aspek salah satunya yaitu kurikulum pembelajaran. Hal ini juga sejalan dengan peraturan yang dikeluarkan oleh Departemen Agama seperti yang dikemukakan oleh Steenbrink (1994) menjelaskan bahwa:
Dalam rangka konvergensi, Departemen Agama menganjurkan supaya pesantren yang tradisional dikembangkan menjadi sebuah madrasah, disusun secara klasikal, dengan memakai kurikulum yang tetap dan memasukkan mata pelajaran umum disamping agama. Sehingga murid di madrasah tersebut mendapatkan pendidikan umum yang sama dengan murid di sekolah umum. (hlm. 97)

Berdasarkan pendapat tersebut maka santri yang mondok di pesanten Albidayah memiliki kesetaraan jenjang pendidikan dengan sekolah pada umumnya. Jika pada awalnya santri yang belajar di pesantren lulusannya tidak dapat melanjutkan ke sekolah umum karena santri hanya mendapat ijazah yang dikeluarkan oleh pesantren. Berbeda dengan santri yang sekaligus belajar di madrasah akan mendapatkan ijazah yang dikeluarkan oleh pemerintah, sehingga santri yang mondok dapat melanjutkan pendidikan ke jenjang yang lebih tinggi.

Adanya pesantren yang di kembangkan menjadi madrasah memberikan kemajuan dalam pendidikan Islam. Seperti yang dikemukakan oleh Suwirta (2009, hlm. 130) menjelaskan bahwa “...the educational system of pesantren experienced the improvement whether from curriculum, classical method, madrasah system or its orientation in educational purpose". Berdasarkan pemaparan tersebut dapat diketahui bahwa sistem pendidikan di pesantren mengalami peningkatan mulai dari kurikulum, metode klasik, sistem madrasah atau orientasi dalam tujuan 
pendidikan. Dengan demikian pesantren yang menjadi lembaga pendidikan di bawah pemerintah akan mengalami perubahan dari segi kurikulum, metode pembelajaran, serta tujuan pendidikan. Selain itu juga materi yang diajarkan tidak hanya meliputi pelajaran agama saja melainkan juga menggabungkan dengan pelajaran umum.

Kurikulum yang diterapkan di pesantren berbeda dengan kurikulum sekolah. Pesantren menggunakan sistem kurikulum yang disusun oleh pihak pesantren itu sendiri. Menurut Aly (2011, hlm. 183) menjelaskan bahwa dari segi kurikulum pesantren selama ini diberi kebebasan oleh negara untuk menyusun dan melaksanakan kurikulum pendidikan secara bebas dan merdeka. Adapun kurikulum yang digunakan oleh pondok Pesantren Albidayah ini menggabungkan beberapa kurikulum atau kurikulum terpadu. Dengan adanya sistem terpadu Pesantren Albidayah mencoba menggabungkan pembelajaran agama dengan pembelajaran umum. Perubahan tersebut tidak hanya untuk menyesuaikan dengan perkembangan zaman melainkan juga atas tuntutan masyarakat sekitar pondok Pesantren Albidayah yang menginginkan adanya sebuah lembaga pendidikan umum.

Masalah utama yang diangkat dalam penelitian ini yakni bagaimana sistem pendidikan pondok Pesantren Albidayah pada masa Kiai Haji Yayat Ruhiyat Sirodj pada tahun 1971-2011. Adapun kurun waktu yang diambil dalam penelitian ini yaitu tahun 1971-2011. Peneliti memiliki alasan tersendiri dalam pemilihan kurun waktu tersebut. Tahun 1971 menjadi awal tahun kajian penelitian karena pada tahun ini pondok Pesantren Albidayah mulai melakukan pembaharuan dalam sistem pendidikan dari tradisional menjadi sebuah lembaga pendidikan resmi dibawah pemerintah. Sedangkan tahun 2011 dijadikan sebagai batas penelitian karena pada tahun ini merupakan akhir dari kepemimpinan $\mathrm{KH}$ Yayat Ruhiyat Sirodj selaku pimpinan pondok pesantren yang dianggap melakukan perubahan besar bagi Pesantren Albidayah.

\section{METODE PENELITIAN}

Metode dalam penelitian ini yaitu metode historis atau metode sejarah. Menurut Gottschalk (2006, hlm. 39) menjelaskan bahwa metode sejarah adalah proses menguji dan menganalisis secara kritis rekaman dan peninggalan masa lampau. Pendapat lainnya mengenai metode sejarah yaitu menurut Sjamsuddin (2012, hlm 63) yang menjelaskan bahwa metode sejarah ialah proses pengkajian, penjelasan, penganalisaan secara kritis terhadap rekaman serta peninggalan masa lampau.

Berdasarkan kedua pendapat di atas dapat disimpulkan bahwa metode historis merupakan suatu cara atau langkahlangkah yang digunakan untuk mengkaji suatu peristiwa, tokoh atau permasalahan yang dianggap layak dan penting yang terjadi pada masa lampau secara deskriptif, kritis, dan analitis. Dalam penelitian sejarah tidak hanya mengungkapkan peristiwa secara kronologis, lebih dari itu perlu adanya kajian dan analisis yang tajam yang didukung dengan teori yang relevan yang kemudian hasilnya dituangkan dalam bentuk tertulis. Terdapat beberapa tahapan dalam metode historis ketika akan melakukan penelitian. Tahapan 
metode historis menurut Sjamsuddin yaitu meliputi heuristik, kritik, interpretasi, dan historiografi.

Heuristik, merupakan sebuah kegiatan mencari sumber-sumber untuk mendapatkan data-data atau materi sejarah, atau evidensi sejarah (Carrard dalam Sjamsuddin, 2012, hlm. 67). Dalam proses pencarian dan pengumpulan sumber sejarah peneliti menggunakan teknik wawancara dan studi literatur. Untuk studi literatur peneliti telah mengunjungi beberapa perpustakaan untuk mengumpulkan berbagai sumber yang relevan dengan topik yang dikaji. Peneliti mengunjungi beberapa perpustakaan yang ada di Bandung. Selain itu peneliti juga mengunjungi pondok Pesantren Albidayah untuk melakukan wawancara dengan ketua yayasan, maupun dengan narasumber yang dianggap dapat memberikan informasi mengenai permasalahan penelitian.

Kritik sumber, pada tahap kritik ini peneliti melakukan verifikasi terhadap informasi yang diperoleh dalam bentuk tertulis maupun lisan, mengenai kebenaran fakta tersebut. Dalam kritik sumber terdapat dua jenis yaitu kritik eksternal dan kritik internal. Kritik eksternal menurut Sjamsuddin (2012, hlm. 132) ialah cara melakukan verifikasi atau pengujian terhadap aspek-aspek "luar" dari sumber sejarah. Adapun kritik eksternal tidak dilakukan pada sumber tertulis dalam bentuk buku, karena keaslian dari buku telah melewati verifikasi yang ketat. Sedangkan kritik internal menurut Sjamsuddin (2012, hlm. 143) menjelaskan bahwa kebalikan dari kritik eksternal, kritik internal sebagaimana yang disarankan oleh istilahnya menekankan aspek "dalam" yaitu isi dari sumber kesaksian. Peneliti melakukan kritik internal terhadap sumber lisan yang didapat melalui proses wawancara, kemudian peneliti membandingkan kesaksian dari narasumber-narasumber tersebut. Kritik internal dilakukan dengan melihat aspek materi yang di sampaikan oleh narasumber, kesesuaian pertanyaan dengan jawaban, dan juga melihat latar belakang keluarga narasumber yang akan mempengaruhi kesaksian mengenai informasi yang diberikan.

Interpretasi, merupakan tahap analisis ataupun menafsirkan sumber-sumber sejarah. Menurut Daliman (2012, hlm. 83) menjelaskan bahwa interpretasi adalah upaya penafsiran atas fakta-fakta sejarah dalam rangka rekonstruksi realitas masa lampau. Dalam kegiatan ini peneliti memberikan penekanan penafsiran dan analisis terhadap fakta dan data dari sumber-sumber primer maupun sekunder yang berkaitan dengan penulisan mengenai pondok Pesantren Albidayah.

Historiografi, merupakan tahap akhir dalam penelitian. Menurut Sjamsuddin (2012, hlm. 185) menjelaskan bahwa historiografi merupakan paparan, penyajian, presentasi atau penampilan (eksposisi) yang sampai kepada dan di baca oleh para pembaca atau pemerhati sejarah. Pada tahap historiografi ini peneliti berusaha menuangkan analisis dan pandangan terhadap fakta-fakta yang telah diperoleh yang disusun dalam bentuk karya ilmiah.

\section{HASIL PENELITIAN}

Pondok Pesantren Albidayah merupakan pondok pesantren tertua di Desa Giriasih, Kecamatan Batujajar, 
Kabupaten Bandung Barat. Albidayah adalah salah satu pesantren yang masih mempertahankan sistem tradisional di tengah kemajuan teknologi. Pesantren Albidayah dikatakan tradisional atau disebut juga dengan pesantren tipe salafi karena materi yang diajarkan yaitu meliputi kitab-kitab klasik. Hal ini sejalan dengan pendapat Mastuhu (1994, hlm. 61) yang menjelaskan bahwa pesantren tradisional (salafiyah) yaitu pesantren yang masih tetap mempertahankan bentuk aslinya dengan semata-mata mengajarkan kitab yang ditulis oleh ulama abad ke-15 M dengan menggunakan bahasa Arab. Dalam perkembangannya pondok Pesantren Albidayah sudah mengalami beberapa kali pergantian pimpinan pesantren. Menurut Endang (wawancara 9 Januari 2018) menjelaskan bahwa pimpinan pesantren tersebut diantaranya:

1) Kiai Haji Asy'arie (1907-1959)

2) Kiai Haji Muhammad Sirodj (19591971)

3) Kiai Haji Yayat Ruhiyat Sirodj (19712011)

Pesantren Albidayah berawal dari sebuah masjid kecil yang didirikan pada tahun 1907 oleh Kiai Haji Asy'arie. Pembelajaran mengenai Islam pada masa Kiai Haji Asy'arie saat itu masih sangat sederhana. Berawal dari masyarakat sekitar yang ikut belajar mengaji di masjid yang didirikan oleh Kiai Haji Asy'arie dengan materi pelajaran yang belum tersusun seperti sekarang. Menurut Mahfudz (wawancara 20 Oktober 2017) menjelaskan bahwa materi yang diajarkan oleh Kiai Haji Asy'arie pada saat itu seperti membaca Al-qur'an, bacaanbacaan shalat, akhlak, tauhid, fiqih, dan ilmu-ilmu fadhu'ain. Sedangkan metode pembelajarannya yaitu menggunakan metode wetonan, sorogan, dan hafalan. Meskipun materi yang diajarkan tersebut cukup banyak akan tetapi belum ada kurikulum pesantren yang tersusun secara baik.

Adapun santri yang belajar kepada Kiai Haji Asy'arie itu pada awalnya berasal dari masyarakat sekitar saja. Akan tetapi menurut Mahfudz (wawancara 20 Oktober 2017) menjelaskan bahwa pada tahun 1940 mulai banyak berdatangan santri-santri dari luar daerah. Sehingga semakin banyak murid-murid dari Kiai Haji Asy'arie. Tidak ada syarat atau ketentuan khusus bagi siapa saja yang ingin menjadi santri dan belajar kepada beliau, yang terpenting yaitu adanya keinginan untuk belajar dan mengamalkan agama Islam.

Sarana dan prasarana pada saat itu masih sangat sederhana, hanya ada masjid dan rumah Kiai. Karena santrinya masih berasal dari wilayah sekitar maka belum didirikan pondok pesantren. Namun seiring dengan berjalannya waktu para santri yang berdatangan dari luar daerah semakin banyak dan tidak memungkinkan mempelajari agama hanya dalam satu hari, maka mulailah didirikan pondok untuk tempat menginap para santri. Sejak saat itu pula mulai berdirinya pondok Pesantren Albidayah.

KiaiHajiAsy'ariewafatpadatahun 1959, kemudian Pesantren Albidayah dipimpin oleh anaknya yaitu Kiai Haji Muhamad Sirodj. Pada masa kepemimpinan beliau pondok Pesantren Albidayah mulai mengalami kemajuan terutama semakin banyak santri yang datang dari luar kota seperti Cianjur, Sukabumi, Tasik, dan Cirebon (wawancara Mahfudz, 20 Oktober 2017). Melihat semakin banyaknya santri 
yang berdatangan dari luar kota maka Kiai Haji Muhammad Sirodj berinisiatif untuk menjadikan Pesantren Albidayah sebagai lembaga pendidikan. Maka beliau memberikan amanah pada putranya yaitu Kiai Haji Yayat Ruhiyat Sirodj untuk menjadikan Pesantren Albidayah sebagai lembaga pendidikan resmi di bawah pemerintah. Tahun 1989 Kiai Haji Muhammad Sirodj wafat kemudian pondok Pesantren Albidayah dilanjutkan oleh Kiai Haji Yayat Ruhiyat Sirodj.

Masa kepemimpinan Kiai Haji Yayat Ruhiyat Sirodj ini dianggap sebagai tonggak perubahan pada pondok Pesantren Albidayah. Adapun perubahan yang signifikan pada masa Kiai Haji Yayat Ruhiyat Sirodj yaitu menjadikan Pesantren Albidayah sebagai lembaga pendidikan yang berada di bawah pemerintah. Dengan demikian sistem pembelajaran pesantren mengalami perubahan dari segi kurikulum, tenaga pendidik, maupun sarana dan prasarana.

Perubahan yang dilakukan oleh Kiai Haji Yayat Ruhiyat Sirodj berawal dari mendirikan SP-IAIN atau Sekolah Persiapan Institut Agama Islam Negeri pada tahun 1971. Berdasarkan pemaparan dari Endang (wawancara 9 Januari 2018) menjelaskan bahwa berdirinya SP-IAIN merupakan saran dari Drs. Utuy Tulmudi. Tujuan didirikannya SP-IAIN yaitu untuk mewujudkan aspirasi dari masyarakat yang pada saat itu menginginkan adanya sekolah lanjutan bagi para santri yang ingin meneruskan ke jenjang perguruan tinggi. SP-IAIN merupakan sekolah yang berada dibawah lembaga pemerintah dengan jenjang pendidikan yang setara dengan Sekolah Menengah Atas (SMA). Pendirian SP-IAIN merupakan bentuk kerjasama antara Pesantren Albidayah dengan Universitas Islam Negeri (UIN) dalam menyelenggarakan pendidikan.

Ketika awal berdirinya SP-IAIN pada tahun 1971 jumlah siswanya hanya ada 16 orang, lalu di tahun 1972 meningkat menjadi 72 orang (Endang, wawancara 9 Januari 2018). Jika dilihat dari peningkatan jumlah siswa tersebut dapat di ketahui bahwa kesadaran masyarakat akan pentingnya pendidikan juga mulai meningkat. Adapun kelebihan dari siswa yang bersekolah di SP-IAIN yaitu dapat melanjutkan ke perguruan tinggi UIN manapun tanpa harus mengikuti jalur tes. Maka bagi siswa yang bersekolah di SPIAIN dapat langsung diterima di UIN.

SP-IAIN tidak berlangsung lama karena pada saat itu peminatnya dianggap masih sangat kurang, maka SP-IAIN yang terdapat di Batujajar dipindahkan ke pusatnya pada tahun 1978 (Mahfudz, wawancara 20 Oktober 2017). Setelah SPIAIN dipindahkan tahun 1980, Yayasan Pesantren Albidayah mendirikan Sekolah Menengah Atas (SMA) Albidayah. Namun pada SMA Albidayah ini siswanya tidak diwajibkan mondok. Kemudian pada tanggal 1 Juli 1993 Kiai Haji Yayat Ruhiyat Sirodj mendirikan Madrasah Aliyah (MA) Albidayah yang mewajibkan seluruh siswanya untuk mondok. Dengan didirikannya MA Albidayah merupakan suatu pembaharuan yang terjadi di pesantren ini karena para santri tidak hanya mempelajari seputar pengetahuan agama saja melainkan juga pengetahuan umum.

Konsep pendidikan yang ditempuh oleh siswa MA Albidayah yaitu sistem pembelajaran full day learning yang berbasis pendidikan pesantren. Oleh 
karena itu seluruh siswa yang menempuh pendidikan di MA Albidayah diwajibkan untuk tinggal di asrama dan sepenuhnya berada dalam pengawasan dan bimbingan serta tanggungjawab lembaga, sehingga kepribadian anak didik akan senantiasa terawasi dan teramati. Adanya ketentuan yang tersebut maka MA Albidayah setiap tahunnya hanya menerima dua kelas rombongan belajar dengan 40-50 siswa perkelasnya (Siti, wawancara 20 Oktober 2017).

Adapun program studi yang diselenggarakan oleh MA Albidayah yaitu program Ilmu Alam yang mengarahkan siswa untuk mengembangkan kemampuannya dalam bidang ilmu-ilmu alam dan eksakta yang berbasis keislaman, sehingga melahirkan lulusan yang dapat melanjutkan ke perguruan tinggi dan dapat berperan dalam pemberdayaan masyarakat dalam bidang eksakta. Selain itu juga terdapat Program Ilmu Sosial yang mengarahkan siswa untuk menguasai ilmu-ilmu sosial kemasyarakatan yang berbasis keislaman, dengan tujuan yang sama yaitu untuk melahirkan lulusan yang dapat melanjutkan ke perguruan tinggi dan dapat berperan dalam kehidupan masyarakat dalam bidang ekonomi, politik, sosial maupun budaya (Siti, wawancara 20 Oktober 2017).

Pada tahun 2006 didirikan Madrasah Tsanawiyah (MTs) Terpadu Albidayah. MTs Terpadu Albidayah juga mewajibkan siswanya untuk tinggal di asrama, sehingga setiap tingkah laku siswa mendapatkan pengawasan dan arahan dari lembaga (Siti, wawancara 20 Oktober 2017). Begitu pula dengan rombongan belajar, MTs Terpadu Albidayah hanya menerima dua kelas saja. Hal tersebut dikarenakan siswanya yang wajib tinggal di asrama sehingga penerimaan siswapun disesuaikan dengan kapasitas daya tampung asrama.

Adapun kurikulum yang diterapkan di Pesantren Albidayah yaitu menggunakan sistem kurikulum terpadu. Dalam penerapannya menggunakan tiga kurikulum yang meliputi Kurikulum Kementrian Pendidikan Nasional yang digunakan pada saat pembelajaran umum disekolah seperti MA dan MTs Albidayah. Untuk pembelajaran di sekolah disesuaikan dengan kurikulum yang diterapkan oleh pemerintah, ketika pemerintah mengharuskan setiap sekolah menggunakan kurikulum KTSP maka MA dan MTs, Albidayah juga mengikuti kurikulum tersebut. Namun untuk saat ini MA dan MTs Albidayah dalam pembelajaran di sekolah menggunakan kurikulum yang terbaru yaitu Kurikulum 2013 sesuai dengan kebijakan dari Kemendikbud (Rijal, wawancara 13 Oktober 2017).

Dalam pembelajaran di sekolah, Albidayah juga menggunakan kurikulum yang dibuat oleh Kementrian Agama. Menurut Liawati (wawancara 9 Januari 2018) menjelaskan bahwa kurikulum yang dibuat oleh Kementrian Agama hanya pada mata pelajaran tertentu saja seperti Pendidikan Agama Islam (PAI) dan Bahasa Arab. Untuk pembelajaran di sekolah seperti MA maupun MTs Albidayah menggunakan kurikulum dari Kementrian Pendidikan Nasional seperti mata pelajaran umum yang meliputi pelajaran IPA, IPS, Bahasa Indonesia, dan lain sebagainya.

Kurikulum yang digunakan dalam pembelajaran di pesantren yaitu menggunakan kurikulum yang disusun 
dan dikeluarkan oleh pihak Pesantren Albidayah dengan materi kajiannya berupa Kitab Kuning dan pembelajaran seputar agama Islam lainnya. Menurut Pesantren Albidayah (2016) menjelaskan bahwa kurikulum yang diselenggarakan di Pondok Pesantren Albidayah terbagi atas intra kurikuler, ko-kurikuler, dan ekstra kurikuler. Intra kurikuler merupakan kegiatan yang melibatkan tenaga pengajar secara langsung dengan sistem klasikal (marhalah). Kegiatan ini merupakan kegiatan pembelajaran kepesantrenan yaitu kajian Kitab Kuning. Ko-kurikuler merupakan kegiatan tambahan santri (muatan lokal) yang wajib diikuti seperti pelatihan dakwah, pelatihan tilawatil Qur'an, pelatihan kaligrafi, pelatihan komputer, keputrian, dan lain-lain. Sedangkan ekstrakurikuler merupakan kegiatan yang boleh dipilih oleh santri dengan tidak mengesampingkan intra maupun ko-kurikuler. Dalam rangka meningkatkan kualitas output santri maka Pesantren Albidayah memfasilitasi santrinya dengan mengadakan kegiatan ekstrakurikuler.

Materi yang diajarkan di pondok Pesantren Albidayah dalam sistem klasifikasi atau tingkatannya menggunakan sistem klasikal atau lebih dikenal dengan istilah marhalah. Adapun sistem klasifikasi atau penjenjangan dilihat berdasarkan kemampuan, daya serap, dan hasil dari Placement Test. Hasil Placement Test tersebut dilakukan pada saat santri mendaftar ke pondok pesantren, sehingga ketika santri masuk pondok pesantren sudah ditempatkan pada tingkatan yang sesuai dengan kemampuannya. Tingkatan marhalah akan mempengaruhi materi kajian pesantren apa saja yang akan dipelajari oleh santri. Adapun sistem marhalah yang ditetapkan oleh pihak Pesantren Albidayah menurut Rijal (wawancara, 13 Oktober 2017) yaitu terdiri dari marhalah i'dady, marhalah awwaly, marhalah wustho, dan marhalah aly.

Berdasarkan marhalah tersebut jika dilihat dari materi yang diajarkan maka pada tingkat marhalah i'dady ini merupakan materi pada tingkat dasar. Materi persiapan sebelum memperdalam al-Qur'an, Hadits, dan Kitab Kuning. Pada tingkat i'dady materi yang diberikan tidak langsung membaca pada kitab melainkan dalam bentuk diktat. Diktat tersebut terdapat dalam bahasa Indonesia maupun bahasa Sunda yang penting dapat dibaca dan dipahami oleh santri. Adapun pada saat pembelajaran tingkat i'dady mulai menulis dan menerjemahkan Kitab Kuning kemudian dibaca bersama-sama. Karena i'dady merupakan tingkat dasar maka hanya sampai pada tahap mengetahui saja.

Pada tingkat selanjutnya yaitu marhalah awwaly dan wustho mulai dijelaskan mengenai Kitab Kuning yang sudah dipelajari tersebut sehingga santri memahami isi dari materi yang diajarkan. Kemudian baru pada marhalah aly santri dituntut untuk tidak hanya memahami akan tetapi harus bisa menerangkan kepada adik kelasnya. Maka dengan demikian kitab yang dipelajarinya hanya itu-itu saja akan tetapi dipelajari secara mendalam.

Dalam pembelajaran di pesantren tentunya terdapat materi yang telah di susun dalam sebuah kurikulum. Namun secara umum terdapat beberapa materi pendidikan Islam yang dipelajari di setiap pesantren-pesanten di Indonesia. Menurut Zuhairini, dkk (2015, hlm. 221) 
menjelaskan bahwa terdapat dua belas materi pendidikan Islam yang di pelajari setelah munculnya sistem madrasah di Indonesia. Adapun materi tersebut diantaranya Fiqih, Nahwu, Shorof, Tafsir, Tauhid, Hadits, Mutsalah Hadis, Mantiq, Ma'ani, Bayan, Badi, dan Ushul Fiqh. Materi seputar pendidikan Islam yang diselenggarakan oleh Pesantren Albidayah meliputi enam kajian Kitab Kuning diantaranya kajian Al-Qur'an, Kajian AlHadits, kajian Fiqih, kajian Tauhid, kajian Nahwu, kajian Shorof.

Di samping Pesantren Albidayah sudah melakukan modernisasi seperti sistem persekolahan akan tetapi tidak melupakan sisi tradisionalnya. Terdapat ciri khas yang menjadikan Albidayah sebagai pesantren yang masih mempertahankan sifat tradisionalnya yaitu dari segi metode pembelajaran yang digunakan. Metode yang masih digunakan hingga saat ini yaitu metode sorogan dan hafalan. Adapun metode sorogan menurut Jailani (2012, hlm. 78) yang menjelaskan bahwa metode sorogan dikenal juga dengan metode layanan individu yaitu metode pembelajaran yang menitikberatkan pada pengembangan kemampuan individu bagi para santri dibawah bimbingan kiai atau ustaz. Sehingga dengan metode ini dapat membantu apabila terdapat santri yang kemampuannya tertinggal dari temantemannya yang lain.

Salah satu kegiatan santri di Pesantren Albidayah yaitu santri belajar mengenai pendidikan Islam biasanya pada ba'da maghrib. Materi yang diajarkan sesuai dengan kurikulum pesantren yang telah di susun. Sedangkan untuk metode pembelajarannya menggunakan metode sorogan. Caranya yaitu santri dibagi menjadi kelompok-kelompok kecil terdiri dari lima sampai sepuluh orang santri yang nantinya akan dibimbing oleh satu tutor. Adapun santri yang ditunjuk yaitu santri yang memiliki kemampuan mengaji yang sudah bagus. Misalnya terdapat kelompok mengaji yang terdiri dari santri yang berada pada tingkat mengaji i'dady atau marhalahnya masih pada tingkat dasar, maka tutor atau santri yang ditunjuk itu harus santri yang berada pada marhalah yang lebih tinggi lagi. Meskipun terdapat pembelajaran dengan sistem tutor sebaya, Pesantren Albidayah juga tetap memberikan pengajaran yang dibimbing oleh guru. Jika pada ba'da maghrib pembelajaran dibimbing oleh santri, maka ba'da isya pembelajaran dibimbing oleh guru. Dengan demikian dapat disimpulkan bahwa suatu pembelajaran tidak hanya didapat dari guru saja melainkan dapat dilakukan oleh teman.

Selain metode sorogan juga terdapat metode hafalan. Menurut Arista (2013, hlm. 25) menjelaskan bahwa metode hafalan adalah kegiatan belajar santri dengan cara menghafal teks tertentu dalam bimbingan dan pengawasan kiai atau uztaz. Para santri diberi tugas untuk menghafal Al-qur'an, hadist, atau kitab tertentu kemudian menyetorkannya ke pengajar. Metode hafalan ini menjadi salah satu alternatif yang digunakan oleh Pesantren Albidayah dalam mengajarkan santri-santrinya. Materi yang dihafalkan oleh para santri seperti bacaan-bacaan Al-Qur'an, Juz'amma, dan Kitab Kuning. Pada saat pembelajaran guru memberikan materi kemudian ditulis oleh para santri dan selanjutnya santri membacakan materi tersebut secara bersama-sama. Kemudian santri akan ditunjuk untuk di tes sejauh mana materi yang dihafalkan. 
Adapun evaluasi yang digunakan oleh Pesantren Albidayah menurut Liawati (wawancara 9 Januari 2018) menjelaskan bahwa untuk mengetahui kemampuan santri maka pihak pesantren mengadakan ujian pesantren seperti di sekolah. Sedangkan untuk batas akhirnya dilihat dari hafal atau tidaknya santri tersebut terhadap materi yang sudah diajarkan. Bedasarkan penjelasan tersebut dapat diketahui bahwa dalam pembelajarannya Pesantren Albidayah lebih menekankan pada pengetahuan dan pemahaman. meskipun hafalan menjadi tolak ukur dalam evaluasi pembelajaran akan tetapi disamping itu Pesantren Albidayah juga menerapkan sistem praktik. Santri yang sudah berada pada marhalah yang tinggi dapat mengajari adik kelasnya. Sehingga kemampuan santri pun sudah dapat terlihat melalui cara tersebut.

Terdapat target hafalan materi yang harus dicapai oleh santri pada setiap bulannya. Menurut Liawati (wawancara 9 Januari 2018) terdapat SKU atau Syarat Kecakapan Umum semacam buku yang berisi materi dan penilaian hafalan santri. Penilaian tersebut dilakukan pada setiap malam selasa dan dicek oleh uztaz sejauh mana santri hafal atau tidaknya materi yang sudah diajarkan. Santri menyetor hafalan materi yang sudah ditentukan kemudian diberi penilaian dan harus selesai sebelum tahun ajaran baru.

Santri yang menempuh pembelajaran di sebuah lembaga pendidikan pada akhir kelulusannya akan mendapat sebuah ijazah maupun transkrip nilai dari lembaga tersebut. Begitu pula dengan pembelajaran di pesantren, akan tetapi ijazah yang dikeluarkan oleh setiap pondok pesantren berbeda-beda. Hal ini dikarenakan pemerintah memberikan kebebasan dalam menerapkan kurikulum bagi setiap pondok pesantren dalam mengelola pendidikannya. Adapun santri yang lulus dari Pesantren Albidayah akan mendapatkan ijazah dari sekolah dan ijazah dari pesantren. Syarat kelulusan santri yaitu berkelakuan baik, lulus Ujian Nasional (UN), dan juga lulus ujian pesantren. Patokan kelulusan santri di Pondok Pesantren Albidayah yaitu dari terpenuhinya setoran hafalan juz'amma dan matan al-Ajrumiyyah. Dengan demikian Syarat Kecakapan Umum (SKU) yang dibuat oleh Pesantren Albidayah berisi mengenai hafalan juz'amma dan matan al-Ajrumiyyah. Hafalan tersebut harus selesai sebagai syarat kelulusan pesantren. Apabila kedua hal tersebut tidak terpenuhi maka santri tidak akan diberi ijazah.

Kehidupan santri yang mondok akan tinggal di tempat yang sudah disediakan oleh pihak pesantren. Mereka dituntut untuk hidup mandiri dengan dibawah pengawasan pihak pesantren. Hal ini berdampakpositifbagipara santriterutama dalam melatih dirinya untuk hidup mandiri jauh dari orang tua. Santri yang mondok selain hidup mandiri juga diajarkan untuk hidup disiplin dengan mengikuti aturan-aturan yang dibuat oleh pesantren dengan sanksi yang sudah ditetapkan apabila terdapat santri yang melanggar atau biasa disebut dengan istilah Ta'zir Bugi. Terdapat sistem pengorganisasian antara santri putra dan santri putri yang disebut OSPA (Organisasi Santri Pondok Pesantren Albidayah). Dengan adanya OSPA tersebut dapat memudahkan santri dalam memenuhi kebutuhan hidupnya dan melatih kerjasama antar santri. 
Syarat untuk dapat diterima di Pesantren Albidayah selain melengkapi administrasi tentunya harus mengikuti tes tulis, tes lisan, dan wawancara. Untuk tes tulis sendiri meliputi pengetahuan umum sedangkan tes lisan meliputi membaca Al-Qur'an dan hafalan surat pendek mulai dari Surat An-Nas hingga Surat at-Takasur. Wawancara dilakukan bertujuan untuk mengetahui kepribadian calon santri tersebut. Sehingga banyak faktor lain di luar akademik yang harus dipertimbangkan.

Keberadaan pondok pesantren tentu akan memberikan dampak bagi lingkungan sekitar, terutama dalam bidang keagamaan, pendidikan dan sosial. Ketiga hal tersebut sangat melekat kuat pada sebuah pesantren. Begitu pula dengan Pesantren Albidayah yang menciptakan nuansa religius terutama di lingkungan Desa Giriasih. Namun seiring dengan berkembangnya Pesantren Albidayah dampak yang dirasa pun tidak hanya pada lingkungan sekitar desa saja melainkan hingga keluar daerah.

Adapun dampak dari berdirinya Pesantren Albidayah dalam bidang keagamaan yaitu selain menyelenggarakan kegiatan pembelajaran bagi santri, Pondok Pesantren Albidayah juga rutin menyelenggarakan kegiatan keagamaan yang melibatkan masyarakat. Adapun kegiatan tersebut seperti Majelis Taklim, Manasik Haji, Istighatsah, dan Ziyarah. Kegiatan tersebut berlangsung secara rutin ada yang setiap satu minggu sekali, satu bulan sekali, ataupun satu tahun sekali. Jam'ah yang datang tidak hanya dari lingkungan sekitar saja melainkan hingga luar daerah.

Selain dalam bidang keagamaan, dampak didirikannya Pesantren Albidayah juga dapat di rasakan dalam bidang pendidikan. Untuk masyarakat Desa Giriasih tentunya Pondok Pesantren Albidayah memiliki peranan yang cukup besar jika dilihat dari sejarahnya. Albidayah ini merupakan lembaga pendidikan keagamaan pertama di desa tersebut. Sehingga masyarakat yang dulunya belum begitu paham mengenai agama Islam dapat belajar di Pesantren Albidayah untuk memperdalam ilmu agama Islam. Bahkan seiring dengan perkembangan Pesantren Albidayah menyelenggarakan pendidikan umum. Masyarakat Desa Giriasih yang pada awalnya masih kurang kesadaran akan bidang pendidikan, namun setelah berdirinya MA Albidayah masyarakat sekitar mulai termotivasi untuk melanjutkan pendidikan.

Lulusan dari Pesantren Albidayah juga memberikan kontribusinya dalam bidang pendidikan. Seperti yang dijelaskan oleh Solihin (wawancara 19 Maret 2018) menjelaskan bahwa:

"Terdapat beberapa alumni dari Pesantren Albidayah yang menjadi guru baik yang mengajar kembali di pesantren ataupun mengajar di sekolah lain. Akan tetapi juga terdapat beberapa alumni yang mendirikan lagi pesantren. Namun tidak secara langsung mendirikan tetapi setelah lulus melanjutkan belajar lagi di pesantren untuk memperdalam ilmunya. Biasanya berawal dari mengajar dulu di pengajian sekitar jika nanti sudah berkembang baru mendirikan pesantren”.

Dari pemaparan tersebut dapat disimpulkan terdapat beberapa alumni dari Pesantren Albidayah yang 
mengamalkan ilmunya untuk diajarkan kembali kepada masyarakat. Meskipun Pesantren Albidayah tidak menjembatani secara khusus lulusannya untuk menjadi tenaga pengajar.

Pesantren Albidayah selain aktif dalam bidang pendidikan dan keagamaan juga aktif dalam bidang sosial seperti mengadakan kerjasama dengan Menteri Negara Riset dan Teknologi Republik Indonesia. Pada tahun 2000 yaitu Dr. Mochammad AS. Hikam, Ph.D bersama pejabat di Badan Tenaga Atom Nasional (BATAN). Kunjungan tersebut bertujuan untuk mengadakan kerjasama dengan Pesantren Albidayah, yakni mengembangkan peralatan pertanian dan perairan modern serta upaya peningkatan SDM masyarakat sekitar pesantren dalam bidang pengembangan hasil pertanian dan peternakan (Albidayah, 2016). Dengan demikian pihak pesantren tidak hanya memajukan masyarakat dalam bidang pendidikan akan tetapi juga membantu masyarakat dalam bidang pertanian dan peternakan. Hal tersebut sesuai dengan masyrakat Desa Giriasih yang sebagian mata pencahariannya merupakan petani.

Selain melakukan kerjasama dengan pemerintah, Pesantren Albidayah juga aktif dalam melakukan dialog mengenai pola pendidikan pesantren dengan beberapa tokoh masyarakat. Adapun dialog tersebut dilakukan pada tahun 2009 dengan Menteri Agama Republik Indonesia, Prof. Dr. KH. Said Aqil Hussein Al-Munawwar, MA. dan Wakil Gubernur Jawa Barat, H. Dede Yusuf (Albidayah, 2016). Tidak hanya mendiskusikan mengenai pola pendidikan pesantren, pihak Pesantren Albidayah juga menuangkan ide-idenya mengenai peran serta pesantren dalam pembangunan pedesaan. Dialog tersebut dilakukan bersama Menteri Koordinator Bidang Kesejahteraan Rakyat Republik Indonesia, H. Yusuf Kalla pada tahun 2010 (Ahmad Tarsa, wawancara 19 Maret 2018). Dengan demikian pondok Pesantren Albidayah tidak hanya memberikan dampak dalam bidang keagamaan dan pendidikan, melainkan dalam bidang sosial dengan menuangkan ide-ide pemikiran dari pihak Pesantren Albidayah dan mendiskusikannya dengan beberapa tokoh masyarakat mengenai peran serta pesantren terhadap pembangunan pedesaan. Sehingga kehadiran pesantren sebagai lembaga menampung aspirasi masyarakat dapat disalurkan pada pemerintah.

\section{SIMPULAN}

Perkembangan Pesantren Albidayah secara signifikan dimulai pada masa kepemimpinan Kiai Haji Yayat Ruhiyat Sirodj. Jika pada masa kepemimpinan Kiai Haji Asy'arie pembelajaran masih dilakukan dengan metode yang tradisional dan fasilitas yang sangat sederhana. Berbeda dengan Kiai Haji Yayat Ruhiyat Sirodj yang sudah menerapkan pembelajaran yang modern serta ditunjang dengan fasilitas pembelajaran yang mencukupi. Meskipun pembelajaran sudah modern akan tetapi metode pembelajaran tradisional juga masih digunakan, hal ini agar tidak menghilangkan ciri khas Pesantren Albidayah sebagai pesantren salafi.

Pada masa Kiai Haji Yayat Ruhiyat Sirodj, Pesantren Albidayah mulai memadukan pengetahuan agama dengan pengetahuan umum. Hal tersebut ditandai dengan didirikannya jenjang pendidikan 
yang berada di bawah lembaga pemerintah yaitu didirikannya SP-IAIN pada tahun 1971. Namun SP-IAIN tidak berlangsung lama maka selanjutnya didirikanlah MA Albidayah dan MTs Terpadu Albidayah. Materi yang diajarkannya pun sudah tersusun dalam sebuah kurikulum terpadu. Dengan demikian materi yang diajarkan pada santri jumlahnya cukup banyak tidak hanya terfokus pada pengetahuan agama saja melainkan pada pengetahuan umum serta mengasah minat dan bakat santri melalui kegiatan ekstrakurikuler maupun kegiatan lain yang diselenggarakan oleh Pesantren Albidayah.

Dengan berdirinya pondok pesantren tentunya akan memberikan dampak untuk masyarakat sekitar maupun bagi masyarakat secara luas. Dampak pondok Pesantren Albidayah dapat dilihat dari beberapa bidang seperti pada bidang keagamaan, pendidikan, dan sosial. Untuk bidang keagamaan sendiri dampak yang sangat terlihat yaitu terdapat acara-acara yang diselenggarakan oleh pihak pondok pesantren salah satunya yaitu kegiatan Majelis Taklim yang dapat diikuti oleh masyarakat. Dalam bidang pendidikan dampak yang sangat terlihat tentunya dari kehadiran pondok pesantren itu sendiri yang menyelenggarakan layanan pendidikan kepada masyarakat baik itu pendidikan formal maupun nonformal. Sedangkan dalam bidang sosial dampak dari adanya pondok Pesantren Albidayah ini yaitu melalui kegiatan-kegiatan diskusi maupun dialog dengan beberapa tokoh pemerintah mengenai pendidikan Pesantren Albidayah dan peningkatan SDM pada masyarakat Desa Giriasih dalam mengembangkan pertanian dan peternakan.
Pondok Pesantren Albdidayah untuk terus dapat berkembang perlu melakukan pembaharuan-pembaharuan dalam berbagai aspek. Sehingga dapat terus menarik minat masyarakat untuk belajar terutama dalam mempelajari agama Islam. Dengan begitu pesantren dapat membantu dalam mencerdaskan generasi penerus bangsa. Disamping perkembangan yang mengikuti modernitas Pesantren Albidayah berusaha untuk mempertahankan ciri khas sebuah pesantren yang telah berdiri selama bertahun-tahun lamanya. Ciri khas tersebut yaitu dengan mempertahankan sistem pembelajarannya yang tradisional.

\section{DAFTAR PUSTAKA}

Aly, A. (2011). Pendidikan Islam Multikultural di Pesantren. Yogyakarta: Pustaka Pelajar.

Arista, V. N. (2013). Manajemen Pembelajaran di Pondok Pesantren Takwinul Muballighin Yogyakarta. Fakultas Ilmu Pendidikan: Universitas Negeri Yogyakarta.

Daliman, A. (2012). Metode Penelitian Sejarah. Yogyakarta: Ombak.

Endang. (2018). Latar Belakang Berdirinya Pondok Pesantren Albidayah.Pesantren Albidayah. 9 Januari 2018.

Gottschalk, L \& Notosusanto, N. (Penyunting). (2006). Mengerti Sejarah. Jakarta: UI Press.

Jailani, I. A. (2012). Pendidikan Pesantren Sebagai Potret Konsistensi Budaya di Tengah Himpitan Modernitas. Jurnal KARSA, 20 (1), hlm. 75-87.

Liawati. (2018). Kurikulum Sekolah dan Pesantren Albidayah. MTs Terpadu Albidayah. 9 Januari 2018. 
Volume 7, No.2, Oktober 2018

Mahfudz. (2017). Latar Belakang Berdirinya Pondok Pesantren Albidayah.Kediaman Mahfudz. 20 Oktober 2017.

Mastuhu. (1994). Dinamika Sistem Pendidikan Pesantren: Suatu Kajian Tentang Unsur dan Nilai Sistem Pendidikan Pesantren. Jakarta; INIS.

Pesantren Albidayah. (2016). Profil Pesantren Albidayah. [Online]. Diakses dari $\quad \mathrm{h} \quad \mathrm{t} t \mathrm{p}: / /$ albidayahcangkorah.blogspot. co.id/2010_04_25_archive.html

Rijal. (2017). Pendidikan Pondok Pesantren Albidayah. Kediaman Rijal. 13 Oktober 2017.

Siti. (2017). Pendidikan di MA Albidayah. Pondok Pesantren Albidayah. 20 Oktober 2017.
Sjamsuddin, H. (2012). Metodologi Sejarah. Yogyakarta: Ombak.

Solihin. (2018). Alumni Pesantren Abidayah. MTs Terpadu Albidayah. 19 Maret 2018.

Steenbrink, K. A. (1994). Pesantren, Madrasah, Sekolah: Pendidikan Islam dalam Kurun Modern. Jakarta: LP3ES.

Suwirta, A. (2009). The History of Education in West Java, Indonesia: From Traditional Era Toward Modern Era. EDUCARE: International Journal for Educational Studies, 1 (2), hlm. 129-140.

Tarsa, A. (2018). Pesantren Albidayah dalam Kehidupan Masyrakat. MA Albidayah. 19 Maret 2018.

Zuhairini, dkk. (2015). Sejarah Pendidikan Islam. Jakarta: Bumi Aksara. 